\title{
Polysialylated Neural Cell Adhesion Molecule-Positive CNS Precursors Generate Both Oligodendrocytes and Schwann Cells to Remyelinate the CNS after Transplantation
}

\author{
H. S. Keirstead,, T. Ben-Hur, ${ }^{2}$ B. Rogister, ${ }^{2,3}$ M. T. O'Leary, ${ }^{1}$ M. Dubois-Dalcq, ${ }^{2}$ and W. F. Blakemore ${ }^{1}$ \\ ${ }^{1}$ Medical Research Council Cambridge Centre for Brain Repair and Department of Clinical Veterinary Medicine, \\ Cambridge, United Kingdom CB3 OES, 2Unité de Neurovirologie et Régénération du Système Nerveux, Institut Pasteur, \\ 75724 Paris, France, and 3Department of Human Physiology and Pathophysiology, University of Liège, 4020 Liège, \\ Belgium
}

Transplantation offers a means of identifying the differentiation and myelination potential of early neural precursors, features relevant to myelin regeneration in demyelinating diseases. In the postnatal rat brain, precursor cells expressing the polysialylated (PSA) form of the neural cell adhesion molecule NCAM have been shown to generate mostly oligodendrocytes and astrocytes in vitro (Ben-Hur et al., 1998). Immunoselected PSA$\mathrm{NCAM}+$ newborn rat CNS precursors were expanded as clusters with FGF2 and grafted into a focal demyelinating lesion in adult rat spinal cord. We show that these neural precursors can completely remyelinate such CNS lesions. While PSA-NCAM+ precursor clusters contain rare $\mathrm{P} 75+$ putative neural crest precursors, they do not generate Schwann cells in vitro even in the presence of glial growth factor. Yet they generate oligodendrocytes, astrocytes, and Schwann cells in vivo when confronted with demyelinated axons in a glia-free area. We confirmed the

Demyelinating diseases of genetic, viral, and/or autoimmune origin such as multiple sclerosis are characterized by progressive or recurrent episodes of focal demyelination that can result in important neurological impairment. There is therefore much interest in finding ways to stimulate remyelination of CNS demyelinated axons. Progress in this field has come from studies on the development of oligodendrocytes, the CNS myelin-forming cells,

\footnotetext{
Received April 9, 1999; revised June 3, 1999; accepted June 14, 1999.

This work was supported by grants from the Multiple Sclerosis Society of Great Britain and Northern Ireland and the Wellcome Trust to W.F.B. H.S.K. held a Research Fellowship from Downing College (Cambridge, UK). T.B.-H. has been supported by a long-term fellowship from the International Human Frontiers in Science Program Organization. B.R. is a Senior Research Associate of the Belgian National Fund for Scientific Research. M.T.O. is a Wellcome Trust veterinary research fellow. We thank Jennifer Gilson, Michael Peacock, Clare Ready, and Sarah Hodge for their valuable technical assistance, Mark Marchionni (Cambridge Neuroscience Inc.) for the gift of GGF2 and excellent advice on the experiments with Schwann cells, Dr. R. Bruzzone for critical reading of this manuscript, and Dr. G. Rougon for advice throughout this study.

Drs. Ben-Hur and Rogister contributed equally to this work. Drs. Dubois-Dalcq and Blakemore contributed equally to the realization of this study.

Correspondence should be addressed to Dr. W. F. Blakemore, Department of Clinical Veterinary Medicine, University of Cambridge, Madingley Road, Cambridge, UK CB3 OES.

Dr. Keirstead's present address: Collaboration on Repair Discoveries, University of British Columbia, Biological Sciences Building, 6270 University Boulevard, Vancouver, British Columbia, Canada V6T 1 Z4.

Dr. Ben-Hur's present address: Department of Neurology, Hebrew University, Hadassah Medical School, P.O. Box 12000, Jerusalem 91120, Israel.

Dr. Rogister's present address: Department of Human Physiology and Pathophysiology, University of Liège, 17 place Delcour, 4020 Liège, Belgium.

Copyright (C) 1999 Society for Neuroscience 0270-6474/99/197529-08\$05.00/0
}

transplant origin of these Schwann cells using $Y$ chromosome in situ hybridization and immunostaining for the peripheral myelin protein $\mathrm{PO}$ of tissue from female rats that had been grafted with male cell clusters. The number and distribution of Schwann cells within remyelinated tissue, and the absence of PO mRNAs in donor cells, indicated that Schwann cells were generated by expansion and differentiation of transplanted $\mathrm{PSA}-\mathrm{NCAM}+$ neural precursors and were not derived from contaminating Schwann cells. Thus, transplantation into demyelinated CNS tissue reveals an unexpected differentiation potential of a neural precursor, resulting in remyelination of CNS axons by PNS and CNS myelin-forming cells.

Key words: progenitor; glial fate; differentiation; astrocyte; polysialylated form of NCAM; remyelination; oligodendrocyte precursor; Schwann cell precursor and on myelin regeneration in a variety of animal models with and without transplantation of glial cells (Dubois-Dalcq and Armstrong, 1990; Franklin and Blakemore, 1997; Duncan, 1996; Fazekerley et al., 1997; Ludwin, 1997). From such studies glial cell transplantation emerges, not only as a powerful tool for investigating aspects of glial cell biology but also as a potential therapeutic approach for human demyelinating disorders. If glial cell transplantation is to be applied in a clinical setting, the transplanted cells should have the potential for expansion both in vitro and in vivo. Because the rate of division and regenerative capacity of oligodendrocyte lineage cells decreases with differentiation (Pfeiffer et al., 1993), there is increased interest in the use of early precursors of oligodendrocytes as a source of donor cells in transplantation studies. In the rodent brain, gliogenesis mostly occurs postnatally, with precursors migrating out of the periventricular zone to generate oligodendrocytes in the white matter and astrocytes in the cortex (Goldman, 1995). It is at that time that one can isolate and immunoselect neural precursors from the rat brain expressing the embryonic polysialylated form of the neural cell adhesion molecule (PSA-NCAM) (Trotter et al., 1989; Grinspan and Franceschini, 1995). When grown on a nonadherent substrate in the presence of FGF2 and thyroid hormone, these PSA-NCAM+ neural precursors generate clusters resembling neurospheres (Ben-Hur et al., 1998). When transferred to an adherent substrate, these precursors differentiate mostly into astrocytes and oligodendrocytes (Ben-Hur et al., 1998). The presence of the PSA moiety on NCAM is not specific for glial 
precursors; rather, it indicates enhanced plasticity of these precursor cells and/or a restriction of their fate (Ben-Hur et al., 1998).

In the present study, we have investigated the differentiation and remyelination potential of PSA-NCAM + neonatal neural precursor clusters after transplantation in a focal demyelinating lesion. Demyelination was induced chemically in adult rat spinal cord after $\mathrm{x}$-irradiation to suppress the remyelination that normally follows demyelination (Blakemore and Patterson, 1978). This treatment leaves a population of demyelinated axons in a glia-free environment that can be used to evaluate the remyelinating and differentiation potential of transplanted glial cell populations without the need to use markers to identify donor cells. We found that PSA-NCAM+ neural precursors remyelinated this lesion very efficiently and that, surprisingly, remyelination was carried out by both oligodendrocytes and Schwann cells. Before transplantation, PSA-NCAM+ clusters contain a small number of cells expressing the low-affinity NGF receptor, and these may represent neural crest or early Schwann cell precursors. However, Schwann cell generation from these precursors was not detected in vitro, even in the presence of glial growth factor 2 (GGF2), which promotes Schwann cell growth. In contrast, when PSA$\mathrm{NCAM}+$ neural precursors were transplanted into a demyelinating environment in the adult CNS, they generated large numbers of Schwann cells, suggesting that the full differentiation potential of neural precursors may sometimes be revealed only by an in vivo environment.

\section{MATERIALS AND METHODS}

Immunopurification, culture, and immunostaining of PSA-NCAM neural precursors. For all the transplantation experiments, the selection of PSA$\mathrm{NCAM}+$ cells from mixed glial cell cultures derived from day 1 postnatal inbred Lewis rat pups was performed after $3 \mathrm{~d}$ as previously described (Ben-Hur et al., 1998). We dissected the cerebral hemispheres, including the periventricular zone and deep nuclei, whereas the olfactory bulbs and tracts were discarded. The cells were subsequently grown into clusters or small neurospheres using FGF2 at $10 \mathrm{ng} / \mathrm{ml}$ for 1-2 weeks (Ben-Hur et al., 1998). To examine in vitro whether Schwann cells or their precursors could also be present in this PSA-NCAM-selected population, the PSA$\mathrm{NCAM}+$ cells were grown in the same serum-free N2 medium (Ben-Hur et al., 1998) supplemented with human PDGF AA at $10 \mathrm{ng} / \mathrm{ml}$ (R \& D Systems Europe, Abingdon, UK) or $0.1-10 \mathrm{ng} / \mathrm{ml} \mathrm{FGF2}$ alone or with GGF2 at $16-20 \mathrm{ng} / \mathrm{ml}$ (courtesy of Mark Marchionni, Cambridge Neuroscience, Cambridge, MA) alone or in addition to $0.1-10 \mathrm{ng} / \mathrm{ml} \mathrm{FGF2}$ (Sigma, St Louis, MO). Cells plated at 80,000 per well onto uncoated 24 well plates grew into clusters, which, after $10 \mathrm{~d}$ of growth, were transferred to dishes ( $35 \mathrm{~mm}$; Falcon) coated with Poly-D-lysine and $1 \mu \mathrm{g} / \mathrm{ml}$ fibronectin (both from Sigma) to allow differentiation in the absence of FGF2 or PDGF but in the presence of GGF2 in some cases. At $5 \mathrm{~d}$, these adherent clusters were stained live with mouse IgG1 anti-rat p75 (1:10; clone 192; Boehringer Mannheim, Mannheim, Germany) followed by goat anti-mouse IgG-FITC (Jackson ImmunoResearch, West Grove, PA). In some cases this P75 staining on live cells was combined with staining with $\mathrm{O} 4 \mathrm{IgM}$ monoclonal antibody followed by goat anti-mouse IgM-Texas Red (Jackson ImmunoResearch) and fixation in $4 \%$ paraformaldehyde.

Schwann cell cultures and their mixing with PSA-NCAM neural cells. Schwann cells were isolated from sciatic nerve from newborn Wistar rats and cultured as described (Dong et al., 1995). Briefly, after dissociation, fibroblasts were removed by immunopanning with mouse anti-rat Thy-1 antibody (Chemicon, Temecula, CA), and the purified Schwann cells (95-98\% pure) were cultured in DMEM containing 5\% fetal calf serum (FCS). At days 3 and 5, cells were treated for $24 \mathrm{hr}$ with $\mathrm{AraC}\left(10^{-5} \mathrm{M}\right)$ to eliminate the remaining fibroblasts. After $6 \mathrm{~d}$ in vitro cells were trypsinized, and 1 million cells were seeded per $35 \mathrm{~mm}$ dish in DMEM and $5 \%$ FCS. After $24 \mathrm{hr}$, this medium was replaced by the modified N2 medium used to cultivate PSA-NCAM-positive CNS precursors (BenHur et al., 1998). In some dishes, FGF2 (20 ng/ml; Sigma) or GGF2 (20 $\mathrm{ng} / \mathrm{ml}$ ) were added and replenished at 72 and $120 \mathrm{hr}$. RNA was extracted after $5 \mathrm{~d}$ of culture in modified $\mathrm{N} 2$ with factors.

In the mixing experiments, 4 million purified PSA-NCAM+ CNS precursors were grown into clusters for $5 \mathrm{~d}$ with $10 \mathrm{ng} / \mathrm{ml}$ of FGF2 as described (Ben-Hur et al., 1998). At that time, 0, 10, 50, 100, and 1000 purified Schwann cells were added to cluster cultures, which were then grown for a further $5 \mathrm{~d}$ in DMEM-N2 with $10 \mathrm{ng} / \mathrm{ml} \mathrm{FGF2} \mathrm{before} \mathrm{RNA}$ extraction (see below).

$R T$-PCR analysis of $P 0$ and $P 75$ expression. Total RNAs were extracted from PSA-NCAM cell clusters, purified Schwann cells, or PSA-NCAM cell clusters mixed with various amounts of Schwann cells using the RNeasy mini kit from Qiagen (Hilden, Germany) following the recommendations of the manufacturer. After spectrophotometric quantification, $500 \mathrm{ng}-1 \mu \mathrm{g}$ were retro-transcribed using an oligo-dT primer and the Superscript II enzyme (Life Technologies, Gaithersburg, MD). Negative controls in which Supercript was omitted were performed. A $50 \mu \mathrm{l}$ PCR reaction was performed using $2 \mu \mathrm{l}$ of the reverse transcription reaction as template. To ensure that the PCR signals detected were not caused by amplification of genomic DNA, control RT-PCR experiments were performed in which cDNA was synthesized without reverse transcriptase (RT). The sequences of the $\mathrm{P} 0$ and actin primers were as described (Lee et al., 1997; Ben-Hur et al., 1998). The P75 primer sequences were as follows: TTGCTTGCTGTTGGAATGAG (forward) and AGCTCCTGGGGAGGAAAATA (reverse), $233 \mathrm{pb}$.

The PCR reaction contained $5 \mu$ l of PCR buffer, $1.5 \mathrm{mM} \mathrm{MgCl}_{2}, 250 \mathrm{ng}$ of each primer, $0.2 \mathrm{~mm}$ of dNTP mix, and $2.5 \mathrm{U}$ of ampliTaq DNA polymerase (Perkin-Elmer, Norwalk, CT). The PCR reaction was run either in a Perkin-Elmer 2400 cycler for the experiments shown in Figure 3 ( 30 cycles; $94^{\circ} \mathrm{C}$ for $30 \mathrm{sec}, 52^{\circ} \mathrm{C}$ for $30 \mathrm{sec}$, and $72^{\circ} \mathrm{C}$ for $1 \mathrm{~min}$ ), or in an MJR PTC200 apparatus $\left(35 \mathrm{cycles} ; 94^{\circ} \mathrm{C}\right.$ for $45 \mathrm{sec}, 60^{\circ} \mathrm{C}$ for $45 \mathrm{sec}$, and $72^{\circ} \mathrm{C}$ for $1 \mathrm{~min}$ ) and was followed by a final extension time at $72^{\circ} \mathrm{C}$ for 10 min (experiments shown in Fig. 4). Ten microliters of the reaction were electrophoresed on a $2 \%$ agarose gel and colored with ethidium bromide.

Focal demyelination of adult rats and transplantation of rat neural precursors. Adult inbred Lewis rats were used in all experiments. Experiments were performed in compliance with Home Office regulations and institutional guidelines. All operations were performed under fluothane anesthesia (Janssen Pharmaceuticals, Berse, Belgium). Animals were $\mathrm{x}$-irradiated $3 \mathrm{~d}$ before intraspinal injection of ethidium bromide $(n=$ $17)$; the $x$-irradiation and ethidium bromide demyelination protocols have been described in detail elsewhere (Blakemore and Crang, 1992). Forty-eight hours after ethidium bromide injection, clusters were washed and resuspended in MEM-HEPES at a concentration of $\sim 6 \times 10^{4}$ cells $/ \mu$ l. Quantification of cells for transplantation was estimated by sampling the concentration of clusters and calculating cell density assuming 30 cells per cluster. A $1 \mu \mathrm{l}$ cell suspension was injected into each animal using the protocol described in detail elsewhere (Blakemore and Crang, 1992).

Analysis of remyelination with or without cell transplantation. Transplanted $(n=12)$ and nontransplanted $(n=5)$ animals were killed $30 \mathrm{~d}$ after lesion induction, and the dissected tissue was prepared for light and electron microscopic examination as previously described (Blakemore and Crang, 1992). Quantification of oligodendrocyte and Schwann cell remyelination was conducted on seven transplanted and two nontransplanted animals. Toluidine blue-stained transverse $1 \mu \mathrm{m}$ resin sections were taken at $1 \mathrm{~mm}$ intervals through the lesions and analyzed at $400 \times$ magnification. Each section was viewed in sequential and nonoverlapping fields using an ocular index grid (Maxta), and oligodendrocyte or Schwann cell remyelination was determined morphologically under each point of gridline intersection (the average number of points analyzed per section was 93). The number of Schwann cell and oligodendrocyte remyelinated points in each section was then multiplied by an axon density correction factor, determined by relating the number of axons within a unit area of Schwann cell remyelination to the number of axons within a unit area of oligodendrocyte remyelination. The numbers from each craniocaudal section were then averaged for each animal. The number of clearly demarcated groups of Schwann cells per lesion was recorded for each craniocaudal section and then averaged for each animal.

Protein $P 0$ and $Y$ chromosome labeling. Paraffin wax-embedded sections were dewaxed, rehydrated, treated with $0.6 \%$ hydrogen peroxide and 10 $\mathrm{mg} / \mathrm{ml}$ proteinase $\mathrm{K}$, and then heated to boiling point in $10 \mathrm{~mm}$ citrate buffer, $\mathrm{pH} \mathrm{6}$, in a microwave oven (O'Leary and Blakemore, 1997). Anti-P0 monoclonal antibody was applied at a dilution of 1:200. Second- 


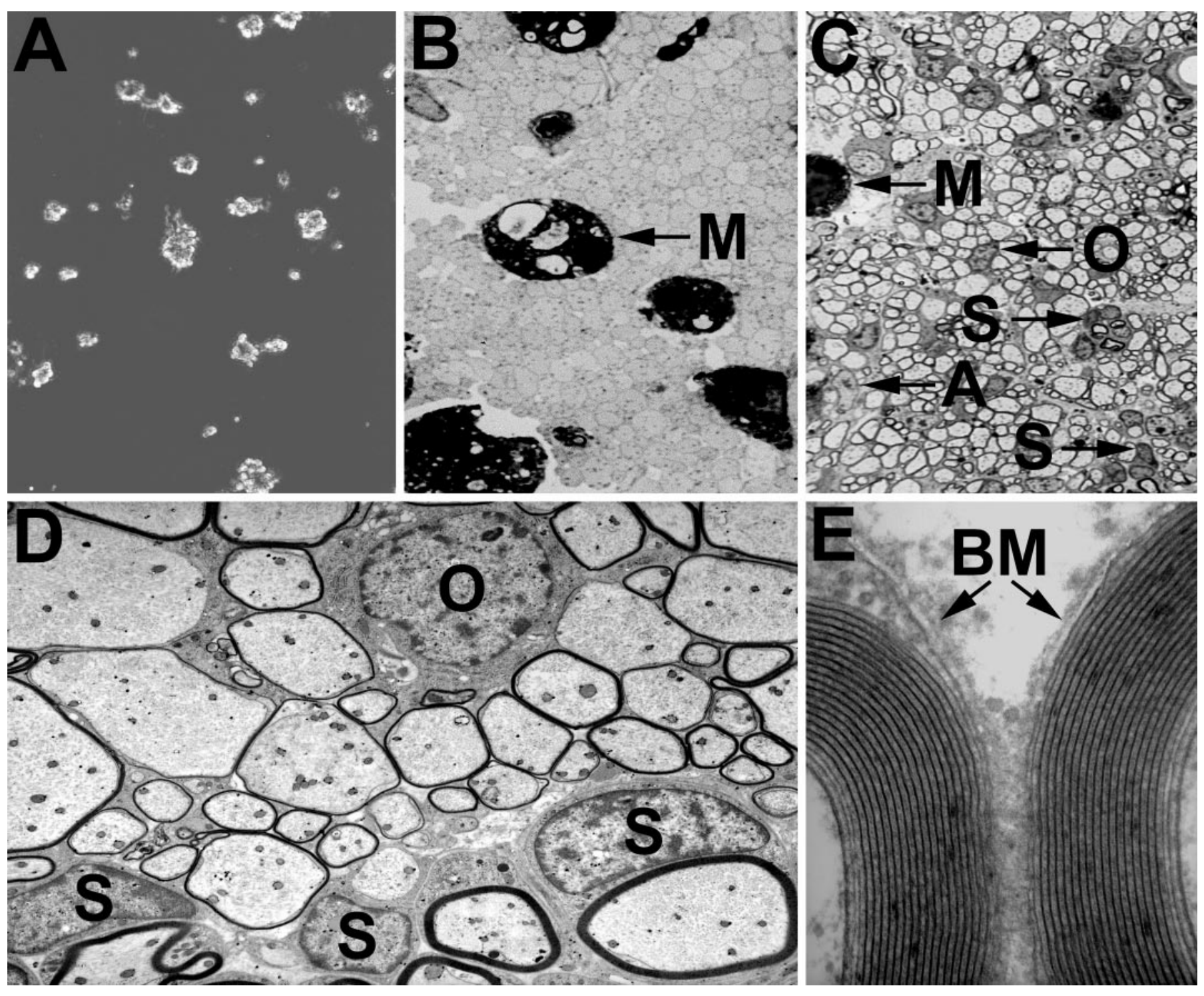

Figure 1. Cluster transplantation results in remyelination. $A$, Phase micrograph of PSA-NCAM+ neural clusters after $10 \mathrm{~d}$ in vitro on a nonadherent surface (immediately before transplant). Grafts consisted of $\sim 60,000$ cells in clusters. $B$, Toluidine blue-stained transverse section of an x-irradiated ethidium bromide lesion in the dorsal funiculus after $30 \mathrm{~d}$. Besides macrophages containing myelin debris $(M)$, the lesion contains naked axons tightly apposed to each other with no evidence of remyelination or glial cell nuclei. $C$, Toluidine blue-stained transverse section of an x-irradiated ethidium bromide lesion $30 \mathrm{~d}$ after transplantation of PSA-NCAM+ neural clusters. Macrophages containing myelin debris $(M)$, oligodendrocytes $(O)$, astrocytes $(A)$, and Schwann cells $(S)$ are present, and virtually all axons are remyelinated. $D$, Electron micrograph of an $\mathrm{x}$-irradiated ethidium bromide lesion $30 \mathrm{~d}$ after transplantation of PSA-NCAM+ neural clusters. An oligodendrocyte $(O)$ is present among remyelinated axons, characterized by thin myelin sheaths. Schwann cells $(S)$, with their nuclei closely apposed to myelin sheaths, are also evident. E, Electron micrograph of an x-irradiated ethidium bromide lesion $30 \mathrm{~d}$ after transplantation of PSA-NCAM+ neural clusters. The myelin sheaths produced by Schwann cells have a greater periodicity than oligodendrocyte myelin and are surrounded by basement membranes $(B M)$. Magnification: $A, 400 \times ; B, C, 600 \times ; D, 12,000 \times ; E, 25,000 \times$.

ary antibody was biotinylated goat anti-mouse heavy and light chain (Sigma). Vectastain ABC (Vector Laboratories, Burlingame, CA) and 3,3'-diaminobenzidine were used for signal visualization. In situ hybridization for the $\mathrm{Y}$ chromosome was done as previously described (O'Leary and Blakemore, 1997). For double labeling, P0 immunohistochemistry was performed as above; then sections were treated with proteinase $\mathrm{K}$, and the $\mathrm{Y}$ chromosome-specific probe was applied to dehydrated sections as described (O'Leary and Blakemore, 1997).

\section{RESULTS}

PSA-NCAM+ precursors remyelinate the CNS after transplantation

PSA-NCAM + neural precursors from postnatal day 1 inbred Lewis rat pups were expanded on a nonadherent surface with FGF2, resulting in the generation of cell clusters after 1-2 weeks
(Fig. 1A). The initial purification yields $85-90 \%$ PSA-NCAM+ cells with most of the remaining cells having an O-2A progenitor phenotype (Ben-Hur et al., 1998). The latter were selected against by growing the PSA-NCAM + neural precursors on a nonadherent surface, resulting in the formation of clusters. These clusters were then transplanted into areas of ethidium bromideinduced demyelination made in the $\mathrm{x}$-irradiated spinal cord of adult Lewis rats. One month after grafting, thoroughly remyelinated lesions were repopulated with astrocytes, oligodendrocytes, and Schwann cells, whereas no remyelination was observed in nontransplanted animals (Table 1, Fig. 1, compare $B, C$ ). Although axons were primarily remyelinated by oligodendrocytes ( $81 \%$ of remyelinated axons on average), there were also numer- 
Table 1. Remyelination by oligodendrocytes and Schwann cells

\begin{tabular}{lllll} 
Animal & $\begin{array}{l}\text { Axons } \\
\text { remyelinated } \\
(\%)\end{array}$ & $\begin{array}{l}\text { Axons remyelinated by } \\
\text { oligodendrocytes }(\%)\end{array}$ & $\begin{array}{l}\text { Axons } \\
\text { remyelinated by } \\
\text { Schwann cells }(\%)\end{array}$ & $\begin{array}{l}\text { Average no. } \\
\text { of Schwann } \\
\text { cell-remyelinated } \\
\text { areas/section }\end{array}$ \\
\hline 1 & 99 & $79(76-81)$ & $21(19-24)$ & $16(11-22)$ \\
2 & 98 & $78(73-84)$ & $22(16-27)$ & $18(15-24)$ \\
3 & 98 & $83(77-88)$ & $17(12-23)$ & $12(10-14)$ \\
4 & 95 & $81(78-83)$ & $19(17-22)$ & $16(10-21)$ \\
5 & 97 & $82(76-93)$ & $18(7-23)$ & $17(12-21)$ \\
6 & 100 & $83(78-87)$ & $17(13-22)$ & $15(13-15)$ \\
7 & 100 & $83(80-84)$ & $17(15-20)$ & $11(9-11)$ \\
8 & 0 & 0 & 0 & 0 \\
9 & 0 & 0 & 0 & 0 \\
\hline
\end{tabular}

Percentage of remyelinated axons within lesions and the relative contribution of oligodendrocytes and Schwann cells to remyelination. Although all animals were $\mathrm{x}$-irradiated and demyelinated, only those animals that received a graft (1-7) were remyelinated; nongrafted animals ( 8 and 9 ) showed no evidence of remyelination. The percentage of remyelinated axons and the percentage of those remyelinated by oligodendrocytes or Schwann cells were not significantly different throughout the craniocaudal length of each of the lesions. Each remyelinated section contained an average of 15 distinct Schwann cell remyelinated areas, indicating clonal expansion at multiple sites. Ranges are given in parentheses.

ous aggregates of myelin-forming Schwann cells (19\% of remyelinated axons on average), which were distributed randomly throughout the lesions (Fig. $1 C, D$, Table 1). Schwann cells were identified on the basis of the presence of a basal lamina and close apposition of their cytoplasm and nucleus to a myelin sheath that had the periodicity of PNS rather than CNS myelin (Fig. 1D,E). In addition, immunoreactivity for protein $\mathrm{P} 0$ (the major protein of peripheral nerve myelin which is made by Schwann cells and is absent from CNS myelin) was a feature of these groups of myelinating cells (Fig. 2A).

\section{Remyelinating Schwann cells are transplant-derived}

Because remyelination is never observed in nontransplanted $\mathrm{x}$-irradiated ethidium bromide lesions (Blakemore and Crang, 1988, 1989; Crang et al., 1992; Groves et al., 1993; Franklin et al., 1996), the Schwann cells present within the remyelinated lesions can be considered to have been generated from the transplanted cells. However, to directly establish the transplant origin of these Schwann cells, we prepared PSA-NCAM+ neural precursors from male rat brain and grafted them into female recipients. This allowed us to distinguish between host and transplanted cells using a Y chromosome-specific probe (Harvey et al., 1992; O'Leary and Blakemore, 1997). In situ hybridization with this probe at 1 month after transplantation revealed that male cells were detected in the lesion and in particular that the cells closely associated with the $\mathrm{P} 0$-immunoreactive myelin sheaths were positive for the $\mathrm{Y}$ chromosome probe (Fig. 2B,C). These experiments therefore confirm that the Schwann cells in the lesions originated from the transplanted PSA-NCAM+ cell preparation.

\section{Schwann cells are unlikely contaminants of PSA-NCAM + CNS precursor clusters}

The presence of transplant-derived remyelinating Schwann cells raised the possibility of contamination of the initial cell preparation with Schwann cells, because this had previously been demonstrated after the transplantation of mixed glial cell preparations (Blakemore and Crang, 1988, 1989). Expression of P0 transcripts is detected in early Schwann cell precursors as well as in neonatal Schwann cells and therefore is a highly specific marker of the Schwann cell lineage (Lee et al., 1997). Another gene of interest is the low-affinity NGF receptor P75 expressed in nonmyelinating
Schwann cells and in multipotential neural crest cells from which Schwann cells derive (Stemple and Anderson, 1992; You et al., 1997). To determine whether Schwann cells and/or their precursors were present in the immunoselected PSA-NCAM+ neural precursor preparation and/or the growing clusters in vitro, we first examined P0 expression by RT-PCR in RNAs prepared from immunopurified PSA-NCAM+ neural precursors and after 2 weeks of growth in FGF2. No signal was detected in these two conditions, whereas $\mathrm{P} 0 \mathrm{mRNA}$ was readily detected in newborn rat sciatic nerve (Fig. $3 A$ ). Generation of Schwann cells may require neuregulin (NRG) isoforms encoded by the NRG1 gene and known to trigger survival of early precursors and mitosis of neonatal Schwann cells (Jessen and Mirsky, 1997). We therefore added one of the NRG isoforms, GGF2, together with FGF2 to the growing PSA-NCAM+ precursors for $10 \mathrm{~d}$. This treatment did not induce the expression of the P0 gene, even after adhesion and differentiation (Fig. 3B). Yet, P0 expression by Schwann cells could have been inhibited by FGF2 (Morgan et al., 1994), which is a growth factor necessary to expand the CNS PSA-NCAM precursors. To exclude this possibility, we examined by RT-PCR whether P0 expression was inhibited in purified neonatal Schwann cells grown for $5 \mathrm{~d}$ in the same FGF2-containing medium as the PSA-NCAM clusters, in GGF-containing medium, or in medium without growth factors. We found $\mathrm{P} 0$ signal in each condition (Fig. 4A). P75 expression was also detected in these three conditions, as predicted for Schwann cells cultured in the absence of neurons. Thus our detection system should trace Schwann cell P0 expression in the PSA-NCAM clusters.

There was still the possibility that Schwann cells were initially present but in insufficient numbers to be detected by P0 RT-PCR assay. To address this question, we mixed small but increasing numbers of Schwann cells to the PSA-NCAM+ CNS clusters, and after $5 \mathrm{~d}$ of growth in FGF2, we analyzed the expression of P0 by RT-PCR (Fig. 4B). P0 signal was detected after addition of 100 Schwann cells to clusters developed from 4 million PSA NCAM+ cells but was absent when $<100$ Schwann cells were added to the clusters. This indicated that $<1$ Schwann cell in 40,000 PSA $\mathrm{NCAM}+$ cells could have been present in the initial preparation without producing a P0 signal detectable by RT-PCR. Because no $\mathrm{P} 0$ signal emerged when CNS clusters were grown in the presence 

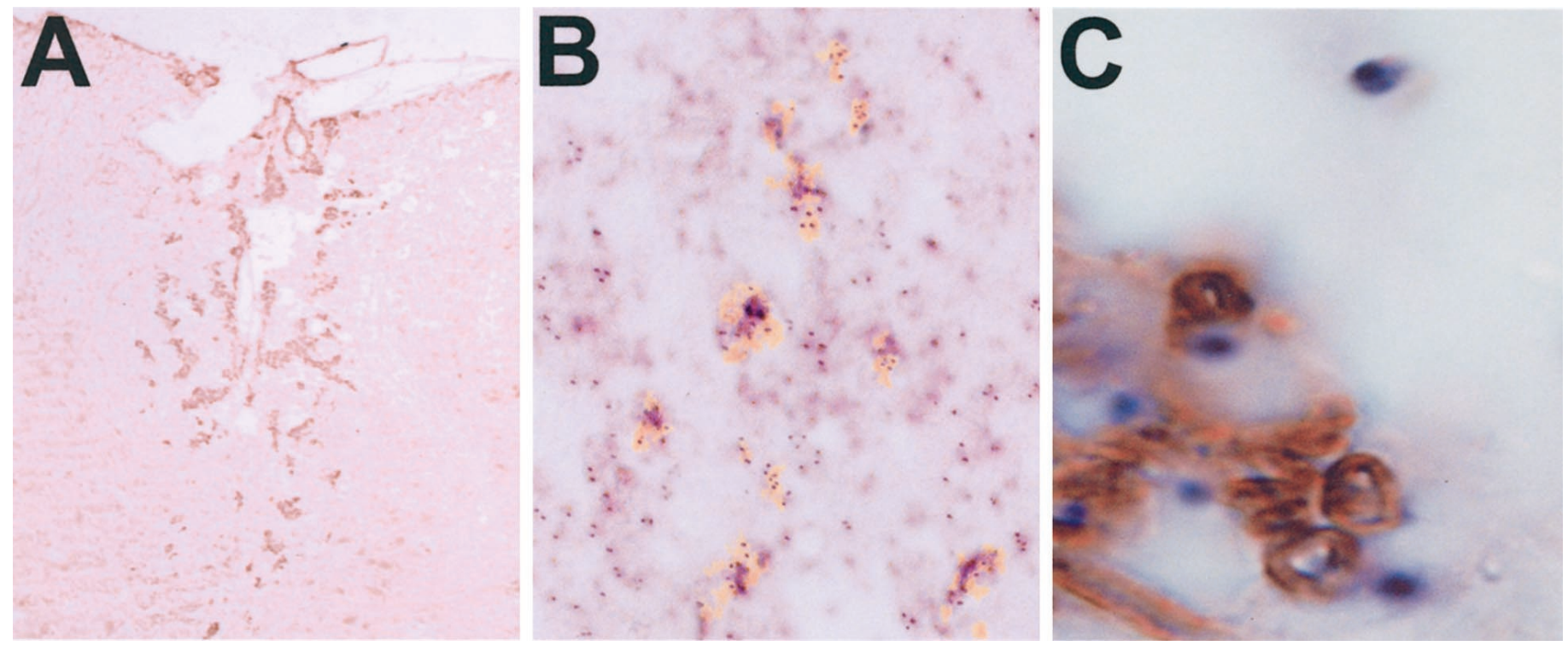

Figure 2. Remyelinating Schwann cells are transplant-derived. A, P0-immunostained transverse section of an x-irradiated, ethidium bromide-lesioned dorsal funiculus $30 \mathrm{~d}$ after transplantation of PSA-NCAM+ neural clusters. P0 immunostaining demonstrates many foci of Schwann cell myelination scattered throughout the lesion. B, Computerized overlay of serial tissue sections hybridized with Y chromosome probe (blue) and immunostained with P0 antibodies for Schwann cell myelin (yellow) in an x-irradiated, ethidium bromide-lesioned female rat $30 \mathrm{~d}$ after transplantation of PSA-NCAM+ neural clusters prepared from male donors. The foci of Schwann cell myelin correspond to regions of high density of transplanted cells. $C$, P0 and $\mathrm{Y}$ chromosome double-labeled transverse section of an x-irradiated, ethidium bromide-lesioned female rat $30 \mathrm{~d}$ after transplantation of PSA-NCAM+ neural clusters prepared from male donors. Intimate apposition of P0-immunostained Schwann cell myelin with Y chromosome-hybridized cell bodies is shown. Magnification: $A, 200 \times ; B, 300 \times ; C, 400 \times$.

of GGF2 (Fig. 3B), we conclude that putative contaminating Schwann cells were very rare or absent and did not expand in vitro

\section{PSA-NCAM+ CNS precursor clusters contain occasional P75+ cells}

The P75 signal was examined in the mixing experiment described above and was found to increase progressively with the numbers of Schwann cells added to the clusters (Fig. 4B). Interestingly, a faint P75 signal was seen in clusters without added Schwann cells, suggesting the presence of rare neural crest cells or early Schwann cell precursors. Accordingly, immunofluorescence revealed the presence of one or two round or bipolar P75+ cells in 7-8.6\% of the clusters grown in PDGF or FGF2 and in $9.2-13.4 \%$ of the clusters grown with GGF2 added to PDGF or FGF2 (Fig. 5). These $\mathrm{P} 75+$ precursors did not increase in number with time in the clusters, and, after adhesion, no groups of P75+ cells with a Schwann cell bipolar phenotype were seen in the migration zone,
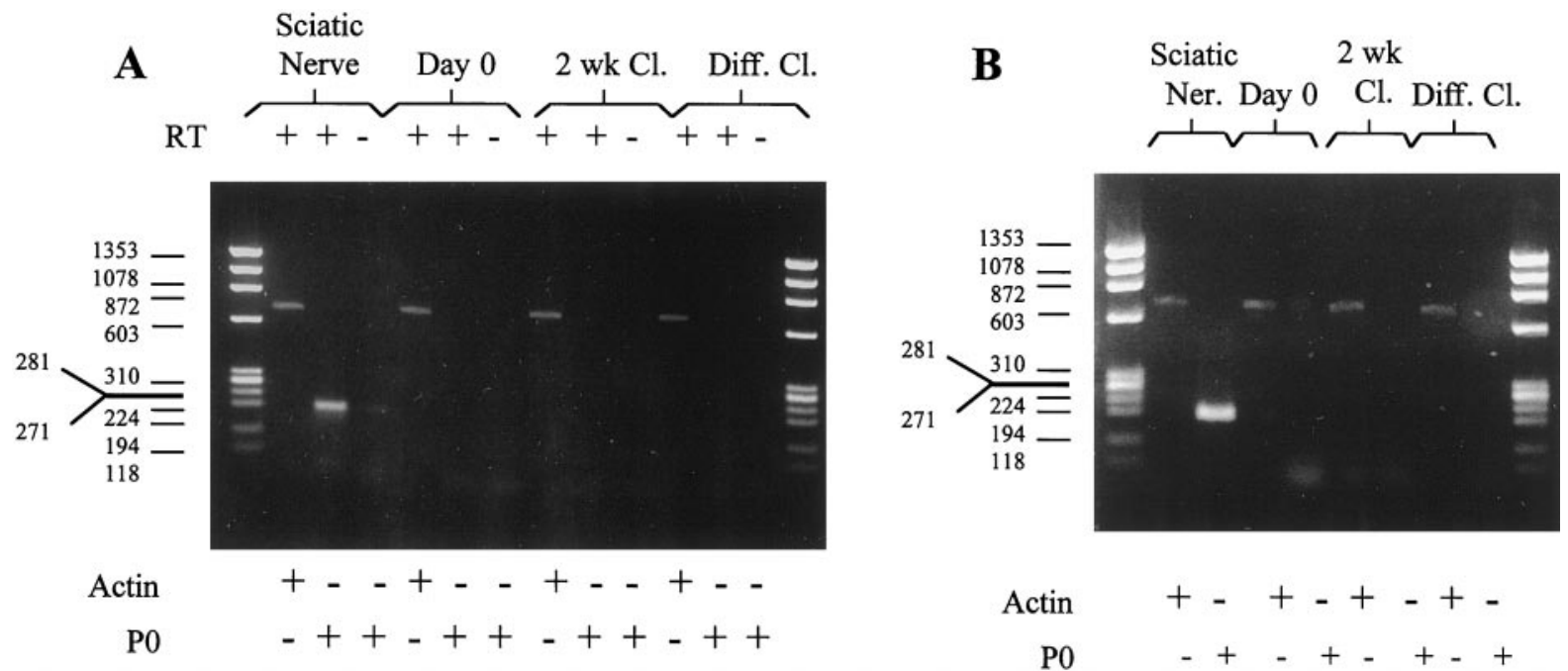

Figure 3. $\mathrm{P} 0$ expression is not detected in the graft preparations. A, RT-PCR of total RNAs extracted from newborn rat sciatic nerve and PSA-NCAM+ cells just after immunopanning (Day 0), after 2 weeks of culture on nonadherent surface in FGF2 (2 wk $\mathrm{Cl}$.), or after differentiation of growing clusters obtained by transfer to poly-D-ornithine-coated surfaces (Diff. $C l$.). P0 expression is absent in PSA-NCAM+ cells in all three experimental conditions. A molecular size marker (174 DNA digested with HaeIII) was run on the right and left. Controls for RT-PCR (RT) correspond to cDNA synthesized without reverse transcriptase. $B$, Immunopurified precursors were treated for $14 \mathrm{~d}$ in vitro with both FGF2 and GGF2. Cell clusters were then transferred to adherent surfaces for differentiation (as in $A$ ) for $5 \mathrm{~d}$ without any growth factor. RNA extraction and the positive controls are as in $A$. Although GGF treatment was performed for $14 \mathrm{~d}$, no P0 expression was observed during in vitro growth and differentiation of the PSA-NCAM precursors. 


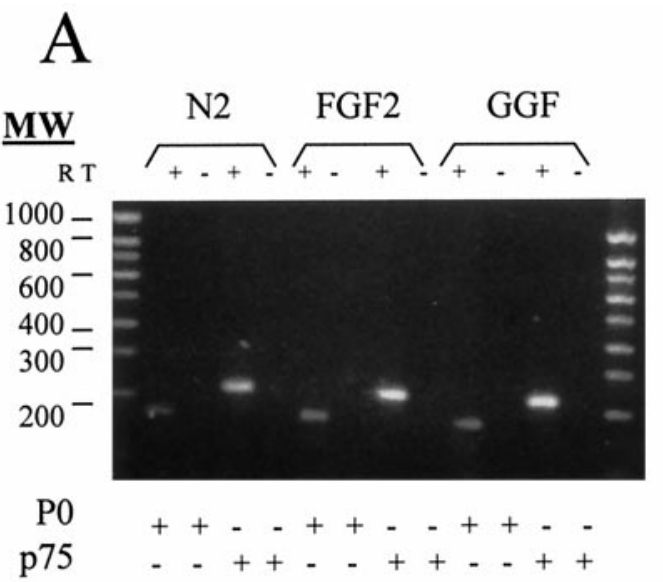

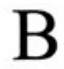

B

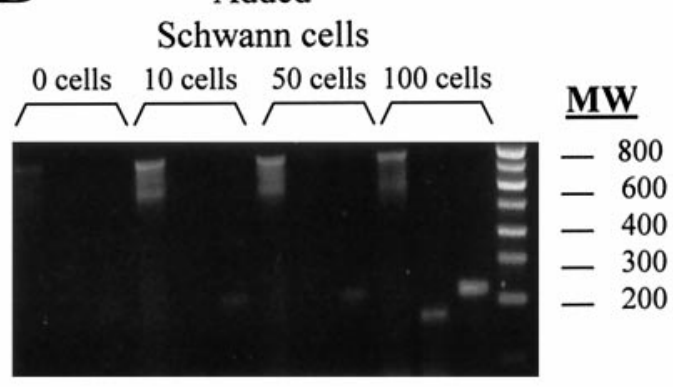

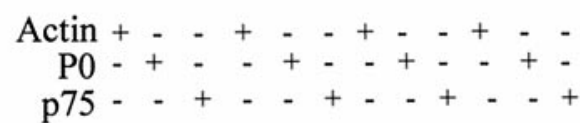

Figure 4. P0 and P75 transcripts are detected in purified Schwann cells and in Schwann cells mixed with PSA-NCAM clusters. RT-PCR of total RNAs extracted from purified Schwann cells $(A)$ or PSA-NCAM CNS clusters to which increasing small numbers of Schwann cells were added $(B)$ is shown. $A$, Signals for P0 and P75 were detected when 1 million Schwann cells were grown in FGF2, GGF2, or defined medium for 5 d. The most intense signal was seen for P75, and the P0 signal was weaker in defined medium alone. P0 signal is observed in Schwann cells cultivated with FGF2 or GGF. B, P0 is observed clearly in the mix of 4 million PSA-NCAM CNS precursors with 100 Schwann cells. These results mean that RT-PCR could detect $0.0025 \%$ Schwann cell contamination in the PSA-NCAM+ clusters. P75 shows a faint signal in the absence of Schwann cells, and that signal increases in intensity proportionally with the number of Schwann cells added. In contrast, the actin signal (seen at $800 \mathrm{MW}$ ) displays equal intensity when 10 , 50 , or 100 Schwann cells were added.

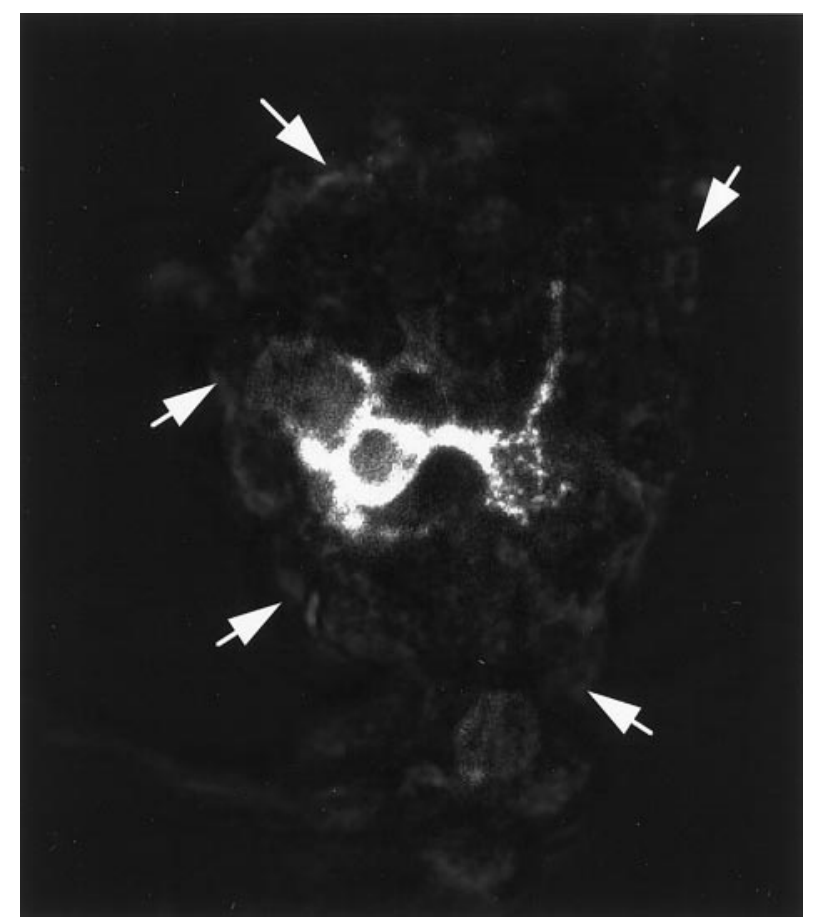

Figure 5. Immunofluorescence staining of a $\mathrm{P} 75+$ precursor cell in a PSA-NCAM cluster. Immunopurified PSA-NCAM+ cells were grown for $10 \mathrm{~d}$ in FGF2 and GGF2 on a nonadherent surface. After adherence they were immunolabeled with P75 antibody, followed by FITC-conjugated secondary antibody. Shown here is one (or two?) P75+ cells with short processes located inside an adherent cluster (delineated by white arrows). These cells did not co-stain with O4 or GFAP. Magnification, 400×.

as would be expected if Schwann cells were generated from neural crest precursors in vitro Moreover, P0 RT-PCR signal was absent after differentiation of cell clusters for $5 \mathrm{~d}$ (Fig. $3 A$ ). However, there were many multiprocessed cells with a phenotype typical of oligodendrocytes that were strongly immunostained with the O4 antibody but only weakly with the P75+ antibody (Casaccia-
Bonnefil et al., 1996). These results suggest that P75+ neural crest, or early Schwann cell precursors of CNS origin, may develop in the clusters. However, these putative Schwann precursors did not generate increasing numbers of Schwann cells in vitro even in the presence of GGF.

Analysis of toluidine blue-stained sections of the grafted animals showed that Schwann cell remyelinated areas were present throughout the remyelinated lesions in all animals, on average 15 Schwann cell remyelinated areas per section (Table 1). The high number of Schwann cell foci indicated that Schwann cells were generated by clonal expansion at multiple sites. The multiple Schwann cell foci and the detection of only small numbers of $\mathrm{P} 75+$ putative neural crest cells in vitro suggest that the P75+ cells are unlikely to be the sole source of the Schwann cells present in the lesions and that the majority of Schwann cells were generated from the PSA-NCAM+ neural precursors in response to the glia-free, axon-rich environment of the demyelinating lesion.

\section{DISCUSSION}

We have generated from the newborn rat brain a CNS donor cell population that is readily expanded in vitro, has a mostly glial fate (Ben-Hur et al., 1998), and results in complete remyelination of demyelinated axons after transplantation in adult rats (Table 1). The extent of remyelination surpassed that observed after transplantation of O-2A progenitor cells (grown with PDGF and FGF2) into similar demyelinated lesions in which a mean of $60 \%$ of axons were remyelinated (Groves et al., 1993). Because PSANCAM expression precedes oligodendrocyte progenitor antigen expression (Grinspan and Franceschini, 1995), our findings extend previous observations that early precursors of oligodendrocytes have a greater remyelinating capacity than cells at more differentiated stages of the lineage (Warrington et al., 1993; Crang and Blakemore, 1997). Thus, with their potential for expansion in vitro, PSA-NCAM+ neural precursors represent an ideal cell population for therapy of chronic demyelinated lesions. Recent studies indicate that human neural precursors express PSA-NCAM (Murray and Dubois-Dalcq, 1997) and can be ex- 
panded with FGF2 (Sabate et al., 1995; Svendsen et al., 1996; Chalmers-Redman et al., 1997; Murray and Dubois-Dalcq, 1997), suggesting that human precursors with a differentiation and remyelination potential similar to that described here could be isolated.

Transplantation not only provides a means of evaluating remyelinating potential of cell preparations but also provides an effective way of evaluating the differentiation potential of multipotent cells (Renfranz et al., 1991; Snyder et al., 1992; Vicario-Abejon et al., 1995; Shihabuddin et al., 1996). When neural precursor cells are implanted into different areas of the developing nervous system, they generate progeny that would normally be generated in that area at the time the cells are grafted. Thus, the same precursor cells can generate Purkinje cells when implanted into the cerebellum and hippocampal neurons when introduced into the hippocampus at the time that these cells are being generated from endogenous precursors (Renfranz et al., 1991). Similarly, when multipotent cells are implanted into pathological areas of the CNS, their differentiation potential is influenced by the environment into which they are placed. Thus, multipotent rat progenitors introduced into the myelin-deficient rat generate only oligodendrocytes (Hammang et al., 1997), while multipotent human progenitors placed into dopaminergic lesions generate neurons and astrocytes (Svendsen et al., 1997). The differentiation of transplanted multipotent cells is therefore strongly influenced by the environmental signals and cellular deficiencies operating at the site of implantation.

The PSA-NCAM+ neural precursors used in this study were isolated from brain hemispheres and the subventricular zone (SVZ) that gives rise to glial cells in the postnatal rat brain (Goldman, 1995). Other populations of CNS cells that express PSA-NCAM may have different fates or potentiality. The anterior SVZ gives rise to PSA-NCAM+ neuronal progenitors, which migrate throughout life in the rostral migratory stream and generate olfactory bulb neurons (Alvarez-Buylla, 1997; Wichterle et al., 1997). The neonatal cerebral cortex contains epidermal growth factor (EGF)-responsive PSA-NCAM+ precursors able to generate neurons and glia (Marmur et al., 1998). However, neurons are rarely observed when our PSA-NCAM+ cell populations grown in FGF2 and thyroid hormone are allowed to differentiate in vitro (Ben-Hur et al., 1998). In addition, PSANCAM-negative neural precursors-excluded by the immunoselection-are multipotential when grown in EGF, whereas they generate more glia when grown in FGF2 and T3 (Ben-Hur et al., 1998). Together these observations indicate that the neonatal PSA-NCAM+ neural precursors used in the present study become restricted to a glial fate during their in vitro expansion. However, we cannot exclude that cortical precursors or olfactory neuron progenitors, if present, may have switched to a glial fate in vitro or after grafting in the spinal cord demyelinating lesion.

Some olfactory bulb-ensheathing cells can also express PSANCAM (Franceschini and Barnett, 1996) and generate a myelinating cell with a Schwann cell phenotype after transplantation into ethidium bromide spinal cord lesions (Franklin et al., 1996). Although contamination of our neural precursor populations by these cells is a possibility, care was taken to separate olfactory bulbs from the cerebral hemispheres for the preparation of the mixed glial cell cultures (Ben-Hur et al., 1998). In addition, olfactory glial cells require astrocyte-conditioned medium or serum for their growth (Franceschini and Barnett, 1996), conditions that were not used to grow our precursors. Thus, the presence within our graft preparations of sufficient numbers of olfactory bulb-ensheathing cells to generate the numerous and dispersed Schwann cell foci within the lesions appears highly unlikely.

Transplantation of PSA-NCAM+ neonatal neural precursors into the glia-free environment of $\mathrm{x}$-irradiated ethidium bromide lesions revealed an unexpected potential of these precursors to generate Schwann cells in addition to oligodendrocytes and astrocytes. Thus the differentiation potential of PSA-NCAM+ neural precursors appears wider in vivo than in vitro where they generate essentially oligodendrocytes and astrocytes (Ben-Hur et al., 1998). By transplanting male cells into female animals, we confirmed that the Schwann cells were transplant-derived. RTPCR analysis for P0 gene transcripts, a specific and sensitive indicator of the Schwann cell lineage (Lee et al., 1997), demonstrated that Schwann cells or their precursors were absent or rare within the PSA-NCAM-immunoselected cells at purification and, if present, were not expanded in vitro with FGF2 or PDGF with or without GGF2. Our finding of P75+ cells inside the clusters indicates that PSA-NCAM+ neural precursors may have the ability to generate neural crest cells and/or early Schwann cell precursors. In support of this is the recent observation that embryonic neural stem cells derived from the telencephalic region generate not only the three CNS cell types but also neural crest cell derivatives in vitro (Hazel et al., 1997). In addition, studies of spinal cord development with chick-quail chimeras suggest that multipotential neural precursors located anywhere in the neural tube have the ability to develop neural crest phenotypes if they encounter an appropriate environment (Sharma et al., 1995). Moreover, clonal analysis of multipotential cells from the rat spinal cord suggests that a common CNS precursor can generate both CNS and PNS phenotypes (Mujtaba et al., 1998). Finally, neural stem cells were recently shown to have unexpected potential to generate cells of the hemopoietic system when engrafted into sublethally irradiated animals (Bjornson et al., 1999). By analogy, we propose that the differentiation potential of PSA$\mathrm{NCAM}+$ neural precursors was extended in vivo and that these cells were instructed to generate both CNS and PNS myelinforming cells by signals present within the irradiated demyelinating lesions devoid of oligodendrocytes and astrocytes.

Our findings demonstrate that selection and subsequent expansion of PSA-NCAM+ neural precursors provides a cell preparation with excellent remyelination potential after transplantation into areas of demyelination in the rat. As cultured PSA-NCAM+ clusters synthesize transcripts for several growth factors, including PDGF and FGF-2 (T. Ben-Hur, B. Rogister, and M. DuboisDalcq, unpublished observations), which enhance their growth (Grinspan and Franceschini, 1995; Ben-Hur et al., 1998), the production of these factors after transplantation of clusters may contribute to cell survival and differentiation in vivo. Moreover, expression of PSA-NCAM has been correlated with cell migration during remyelination (Nait Oumesmar et al., 1995). Because PSA-NCAM + cells can be isolated from the embryonic human CNS (Murray and Dubois-Dalcq, 1997), our results represent an important step in the development of glial cell transplantation strategies for the treatment of diseases associated with chronic demyelination. A further novel observation was that the presence of axon signals within a lesion devoid of astrocytes revealed an unexpected potential of PSA-NCAM+ neural precursors to generate Schwann cells. 


\section{REFERENCES}

Alvarez-Buylla A (1997) Neurogenesis in the adult brain: prospects for brain repair. In: Isolation, characterization and utilization of CNS stem cells (Gage F, Christen Y, eds), pp 87-100. Berlin: Springer.

Ben-Hur T, Rogister B, Murray K, Rougon G, Dubois-Dalcq M (1998) Growth and fate of PSA-NCAM+ precursors of the neonatal brain. J Neurosci 18:5777-5788.

Bjornson CRR, Rietze RL, Reynolds BA, Magli MC, Vescovi AL (1999) Turning brain into blood: a hematopoietic fate adopted by adult neural stem cells in vivo. Science 283:534-537.

Blakemore WF, Crang AJ (1988) Extensive oligodendrocyte remyelination following injection of cultured central nervous system cells into demyelinating lesions in adult central nervous system. Dev Neurosci 10:1-10.

Blakemore WF, Crang AJ (1989) The relationship between type-1 astrocytes, Schwann cells and oligodendrocytes following transplantation of glial cell cultures into demyelinating lesions in the adult rat spinal cord. J Neurocytol 18:519-528.

Blakemore WF, Crang AJ (1992) Transplantation of glial cells into areas of demyelination in the adult rat spinal cord. In: Neural transplantation: a practical approach. (Dunnett SB, Bjorklund A, eds), pp 105-122. Oxford: Oxford UP.

Blakemore WF, Patterson RC (1978) Suppression of remyelination in the CNS by x-irradiation. Acta Neuropathol (Berl) 42:105-113.

Casaccia-Bonnefil P, Carter BD, Dobrowsky RT, Chao MV (1996) Death of oligodendrocytes mediated by the interaction of nerve growth factor with its receptor p75. Nature 383:716-719.

Chalmers-Redman RME, Priestley T, Kemp JA, Fine A (1997) In vitro propagation and inducible differentiation of multipotential progenitor cells from human fetal brain. Neuroscience 76:1121-1128.

Crang AJ, Blakemore WF (1997) Attempts to produce astrocyte cultures devoid of oligodendrocyte generating potential by the use of antimitotic treatment reveal the presence of quiescent oligodendrocyte precursors. J Neurosci Res 48:64-71.

Crang AJ, Franklin RJM, Blakemore WF, Noble M, Barnett SC, Groves A, Trotter J, Schachner M (1992) The differentiation of glial cell progenitor populations following transplantation into non-repairing CNS glial lesions in adult animals. J Neuroimmunol 40:243-254.

Dong Z, Brennan A, Liu N, Yarden Y, Lefkowitz G, Mirsky R, Jessen KR (1995) Neu differentiation factor is a neuron-glia signal and regulates survival, proliferation, and maturation of rat Schwann cell precursors. Neuron 15:585-596.

Dubois-Dalcq M, Armstrong R (1990) The cellular and molecular events of central nervous system remyelination. Bioessays 12:569-576.

Duncan ID (1996) Glial cell transplantation and remyelination of the central nervous system. Neuropathol Appl Neurobiol 22:87-100.

Fazekerley JK, Amor S, Nash AA (1997) Animal models systems of MS. In: Molecular biology of multiple sclerosis (Russell WC, ed), pp 255274. New York: Wiley.

Franceschini IA, Barnett SC (1996) Low-affinity NGF-receptor and E-N-CAM expression define two types of olfactory nerve ensheathing cells that share a common lineage. Dev Biol 173:327-334.

Franklin RJM, Blakemore WF (1995) Glial cell transplantation and plasticity in the O-2A lineage-implications for CNS repair. Trends Neurosci 18:151-156.

Franklin RJM, Blakemore WF (1997) Transplanting oligodendrocyte progenitors into the adult CNS. J Anat 190:23-33.

Franklin RJM, Gilson JM, Franceschini LA, Barnett SC (1996) Schwann cell-like myelination following transplantation of an olfactory bulb ensheathing line into areas of demyelination in the adult CNS. Glia 17: 217-224.

Goldman JE (1995) Lineage, migration and fate determination of postnatal subventricular zone cells in the mammalian CNS. J Neuroncol 24:61-64.

Grinspan JB, Franceschini BJ (1995) Platelet-derived growth factor is a survival factor for PSA-NCAM+ oligodendrocyte pre-progenitor cells. J Neurosci Res 41:540-551.

Groves AK, Barnett SC, Franklin RJM, Crang AJ, Mayer M, Blakemore WF, Noble M (1993) Repair of demyelinated lesions by transplantation of purified O-2A progenitor cells. Nature 362:453-455.

Hammang JP, Archer DR, Duncan ID (1997) Myelination following transplantation of EGF-responsive neural stem cells into a myelindeficient environment. Exp Neurol 147:84-95.

Harvey AR, Fan Y, Beilharz MW, Grounds MD (1992) Survival and migration of transplanted male glia in adult female mouse brain monitored by a Y-chromosome-specific probe. Mol Brain Res 12:339-343.
Hazel TG, Panchison P, McKay RDG (1997) Regional plasticity of multipotent precursors from the developing CNS. Soc Neurosci Abstr 23:131.

Jessen KR, Mirsky RJ (1997) Developmental regulation of Schwann cell precursors and Schwann cell generation in the rat. J Anat 191:501-505.

Lee M-J, Brennan A, Blanchard A, Zoidl G, Dong Z, Tabernero A, Zoidl C, Dent MAR, Jessen KR, Mirsky R (1997) P0 is constitutively expressed in the rat neural crest and embryonic nerves and is negatively and positively regulated by axons to generate non-myelin-forming and myelinforming Schwann cells, respectively. Mol Cell Neurosci 8:336-350.

Ludwin SK (1997) The pathobiology of the oligodendrocyte. J Neuropathol Exp Neurol 56:111-124.

Marmur R, Mabie PC, Gokhan S, Song Q, Kessler JA, Mehler MF (1998) Isolation and developmental characterization of cerebral cortical multipotent progenitors. Dev Biol 204:577-591.

Morgan L, Jessen KR, Mirsky R (1994) Negative regulation of the P0 gene in Schwann cells: suppression of P0 mRNA and protein induction in cultured Schwann cells by FGF2 and TGF Beta1, Beta2 and Beta 3. Development 120:1399-1409.

Mujtaba T, Mayer-Proschel M, Rao MS (1998) A common neural progenitor for the CNS and PNS. Dev Biol 1:1-15.

Murray K, Dubois-Dalcq MJ (1997) Emergence of oligodendrocytes from human neural spheres. Neurosci Res 50:146-156.

Nait Oumesmar B, Vignais L, Duhamel-Clerin E, Avellana-Adalid V, Rougon G, Baron-Van Evercooren A (1995) Expression of the highly polysialylated neural cell adhesion molecule during postnatal myelination and following chemical demyelination of the adult spinal mouse spinal cord. Eur J Neurosci 7:480-491.

O'Leary MT, Blakemore WF (1997) Use of a rat Y chromosome probe to determine the long-term survival of glial cells transplanted into areas of CNS demyelination. J Neurocytol 26:191-206.

Pfeiffer SE, Warrington AE, Bansal R (1993) The oligodendrocyte and its many processes. Trends Cell Biol 3:191-197.

Renfranz PJ, Cunningham MG, McKay RDG (1991) Region-specific differentiation of the hippocampal stem cell line HiB5 upon implantation into the developing mammalian brain. Cell 66:713-729.

Sabate O, Horellou P, Vigne E, Colin P, Perricaudet M, Buc-Caron MH, Mallet J (1995) Transplantation to the rat brain of human neural progenitors that were genetically modified using adenoviruses. Nat Genet 9:256-260.

Sharma K, Korade Z, Frank E (1995) Late-migrating neuroepithelial cells from the spinal cord differentiate into sensory ganglion cells and melanocytes. Neuron 14:143-152.

Shihabuddin LS, Brunschwig JP, Holets VR, Bunge MB, Whittemore SR (1996) Induction of mature neuronal properties in immortalized neuronal precursor cells following grafting into neonatal CNS. J Neurocytol 25:101-111.

Snyder EY, Deitcher DL, Walsh C, Arnold-Aldea S, Hartwieg EA, Cepko CL (1992) Multipotent neural cell lines can engraft and participate in development of mouse cerebellum. Cell 68:33-51.

Stemple DL, Anderson DJ (1992) Isolation of a stem cell for neurons and glia from the mammalian neural crest. Cell 71:973-85.

Svendsen CN, Clarke DJ, Rosser AE, Dunnett SB (1996) Survival and differentiation of rat and human epidermal growth factor-responsive precursor cells following grafting into the lesioned adult central nervous system. Exp Neurol 137:376-388.

Svendsen CN, Caldwell MA, Shen J, ter Borg MG, Rosser AE, Tyers P, Karmiol S, Dunnett SB (1997) Long-term survival of human central nervous system progenitor cells transplanted into a rat model of Parkinson's disease. Exp Neurol 148:135-146.

Trotter J, Bitter-Suermann D, Schachner M (1989) Differentiationregulated loss of the polysialylated embryonic form and expression of the different polypeptides of the neural cell adhesion molecule by cultured oligodendrocytes and myelin. J Neurosci Res 22:369-383.

Vicario-Abejon C, Cunningham MG, McKay RDG (1995) Cerebellar precursors transplanted to the neonatal dentate gyrus express features charachteristic of hippocampal-neurons. J Neurosci 15:6351-6363.

Warrington AE, Barbarese E, Pfeiffer SE (1993) Differential myelinogenic capacity of specific developmental stage of the oligodendrocyte lineage upon transplantation into hypomyelinating hosts. J Neurosci Res 34:1-13.

Wichterle H, Garcia-Verdugo J-M, Alvarez-Buylla A (1997) Direct evidence for homotypic, glia-independent neuronal migration. Neuron 18:777-791.

You S, Petrov T, Chung PH, Gordon T (1997) The expression of the low affinity nerve growth factor receptor in long-term denervated Schwann cells. Glia 20:87-100. 